\title{
ANALISIS PENGARUH UKURAN PERUSAHAAN DAN KOMISARIS INDEPENDEN TERHADAP PENGUNGKAPAN INTELLECTUAL CAPITAL DENGAN PROFITABILITAS SEBAGAI VARIABEL MODERASI
}

(Studi Empiris pada perusahaan yang terdaftar di Indeks Kompas 100 Bursa Efek Indonesia periode 2015-2019)

\author{
Dimas Wicaksono \\ Universitas Islam As Syafiiah \\ Email : dimas.wicaksono22@ymail.com
}

\begin{abstract}
This study aims to examine the influence of the company and independent commissioners on intellectual capital disclosure with profitability as a moderating variable. The dependent variable in this study is disclosure of intellectual capital. While the independent variables in this study are company size and independent commissioners, while profitability is the moderating variable. The population in this study are companies listed on the Kompas 100 Index of the Indonesia Stock Exchange for the period 2015-2019. Methods of data collection in this study using content analysis methods from 22 sample companies. To analyze the relationship between the independent variable and the dependent variable with the panel data regression analysis method. The results of this study indicate that company size has a positive effect on intellectual capital disclosure. Independent commissioners have a positive effect on intellectual capital disclosure. Profitability of the effect of company size on intellectual capital disclosure. Profitability is not able to influence the effect of independent commissioners on intellectual capital disclosure.
\end{abstract}

Keywords: Company Size, Independent Commissioner, Intellectual Capital Disclosure, Profitability.

\begin{abstract}
Abstrak
Penelitian ini bertujuan untuk menguji pengaruh ukuran perusahaan dan komisaris independen terhadap pengungkapan intellectual capital dengan profitabilitas sebagai variable moderating. Variabel dependen dalam penelitian ini adalah pengungkapan intellectual capital. Sementara variabel independen dalam penelitian ini adalah ukuran perusahaan dan komisaris independen, sedangkan profitabilitas sebagai variable moderating. Populasi dalam penelitian ini adalah perusahaan yang terdaftar di Indeks Kompas 100 Bursa Efek Indonesia periode 2015-2019. Metode Pengumpulan data pada penelitian ini menggunakan metode content analysis dari 22 sampel perusahaan. Untuk menganalisis hubungan antara variabel independen dengan variabel dependen dengan metode analisis regresi data panel. Hasil penelitian ini menunjukkan bahwa ukuran perusahaan berpengaruh signifikan positif terhadap pengungkapan intellectual capital. Komisaris independen berpengaruh positif terhadap pengungkapan intellectual capital. Profitabilitas memperkuat pengaruh ukuran perusahaan terhadap pengungkapan
\end{abstract}


intellectual capital. Profitabilitas tidak mampu memperkuat pengaruh komisaris independen terhadap pengungkapan intellectual capital.

\section{Kata kunci: Ukuran Perusahaan, Komisaris Independen, Pengungkapan Intellectual Capital, Profitabilitas.}

\section{Pendahuluan}

\section{Latar Belakang}

Globalisasi memaksa perusahaan-perusahaan untuk mengubah cara mereka agar tetap mampu bertahan dalam menjalankan bisnisnya. Perusahaan perlu menonjolkan informasi intelektual dengan melakukan pengungkapan informasi tersebut untuk menaikan nilai perusahaan agar dapat menarik perhatian investor. Laporan yang diungkapkan oleh perusahaan adalah berupa laporan keuangan

Laporan keuangan adalah laporan yang berisi informasi-informasi penting yang menggambarkan keadaan sebuah perusahaan dengan tujuan menyediakan informasi bagi investor, kreditor, dan pemakai informasi eksternal lainnya yang digunakan untuk pengambilan keputusan investasi (Kieso et al, 17: 2013).

Terdapat 2 jenis pengungkapan informasi keuangan, yaitu pengungkapan wajib (mandatory disclosure), adalah pengungkapan yang diwajibkan oleh peraturan pemerintah atau peraturan yang berlaku. Selanjutnya adalah pengungkapan yang bersifat sukarela (voluntary disclosure) yaitu pengungkapan yang tidak diwajibkan oleh peraturan yang berlaku salah satu isinya adalah intellectual capital (Yadiati dan Mubarok, 70: 2017).

Firer \& Williams dalam (Ulum, 2017:15) mendefinisikan intellectual capital (IC) merupakan informasi dan pengetahuan yang diaplikasikan dalam pekerjaan atau proses bisnis untuk menciptakan sebuah nilai bagi perusahaan.

Intellectual capital secara umum terbagi menjadi 3 komponen yaitu humcapital atau pengetahuan yang didasarkan oleh manusia, structural capital atau pengetahuan mengenai yang ada didalam perusahaan, dan relational capital atau pengetahuan mengenai pihak eksternal (Ulum, 2017:84).

Pengungkapan intellectual capital yang terjadi pada perusahaan yang terdaftar di Indeks Kompas 100 dari tahun 2015-2019 rata-rata pengungkapan intellectual capital pada perusahaan Indeks Kompas 100, terjadi fluktuasi pada tahun 2015-2016 namun dapat dilihat terdapat kenaikan yang signifikan terjadi dari tahun 2016-2019. Faktor-faktor yang mempengaruhi pengungkapan intellectual capital salah satunya adalah ukuran perusahaan dan Komisaris Independen. Penelitian ini menguji variabel ukuran perusahaan dan komisaris independen didasarkan pada hasil penelitian sebelumnya yang tidak konsisten.

Variabel independen pertama yang digunakan dalam penelitian ini adalah ukuran perusahaan. Menurut Bambang Riyanto (2001) dalam (Kariyoto, 2018:57) ukuran perusahaan menggambarkan besar kecilnya perusahaan yang ditunjukkan pada total aktiva, jumlah penjualan dan rata-rata penjualan. Alasan penggunaan ukuran sebagai variabel yang mempengaruhi pengungkapan intellectual capital adalah berdasarkan teori stakeholders, manajemen akan berupaya untuk memenuhi kepentingan stakeholders dengan melakukan pengungkapan yang berlebih, termasuk pengungkapan Intellectual Capital.

Penelitian terkait ukuran perusahaan yang telah dilakukan oleh Astuti \& Wirama (2016) dengan hasil ukuran perusahaan berpengaruh signifikan terhadap intellectual 
capital. Namun hasil ini tidak sejalan dengan penelitian Asfahani (2017) yang mengungkapkan bahwa ukuran perusahaan tidak memiliki pengaruh terhadap pengungkapan intellectual capital.

Variabel independen kedua yang digunakan dalam penelitian ini adalah komisaris independen. Menurut Peraturan Otoritas Jasa Keuangan Nomor 55 /POJK.03/2016 Komisaris Independen merupakan anggota Dewan Komisaris yang tidak memiliki hubungan keuangan, kepengurusan, kepemilikan saham dan atau hubungan keluarga dengan anggota Direksi, anggota Dewan Komisaris lain dan atau pemegang saham pengendali. Komisaris independen mengawasi para pemegang saham dan perilaku para manajer perusahaan (Sutantoputra \& Simagunsong, 2018:38).

Penelitian terkait komisaris independen yang dilakukan oleh Poluan dan Nugroho (2015) menemukan bahwa komisaris independen berpengaruh positif terhadap Pengungkapan intellectual capital, sedangkan pada penelitian Indah dan Handayani (2017) menemukan bahwa komisaris independen tidak berpengaruh terhadap pengungkapan intellectual capital.

Dalam penelitian ini peneliti menambahkan penggunaan variabel Profitabilitas sebagai variabel moderating. Menurut (Wijayanto, 2012:254) Profitabilitas merupakan perhitungan untuk menilai kemampuan perusahaan dalam mencari keuntungan. Choo and Bontis (2010:167) menyatakan apabila profitabitas perusahaan baik maka akan semakin tinggi perusahaan dalam mengungkapkan informasi sukarela ke para stakeholders yang terdiri dari kreditur, supplier, dan juga investor untuk pengambilan keputusan.

Indikator profitabilitas yang digunakan dalam penelitian ini adalah Return on Aseet. Return on Asset (ROA) adalah rasio yang menunjukkan hasil (return) atas aset yang digunakan dalam perusahaan (Kasmir, 2015:159).

Berdasarkan uraian latar belakang diatas penelitian ini mengambil judul "Analisis Pengaruh Ukuran Perusahaan Dan Komisaris Independen Terhadap Pengungkapan Intellectual Capital Dengan Profitabilitas Sebagai Variabel Moderating"

\section{Tujuan Penelitian}

Berdasarkan latar belakang, maka penelitian ini bertujuan untuk :

a. Untuk mengetahui pengaruh Ukuran perusahaan terhadap pengungkapan Intellectual Capital.

b. Untuk menegetahui pengaruh Komisaris Independen terhadap pengungkapan Intellectual Capital.

c. Untuk mengetahui apakah Profitabilitas memoderasi Ukuran Perusahaan terhadap Intellectual Capital.

d. Untuk mengetahui apakah Profitabilitas memoderasi Komisaris Independen terhadap Intellectual Capital.

3. Kontribusi Penelitian

a. Manfaat Teoritis

Penelitian ini diharapkan dapat menjadi sumber referensi bagi penelitian di masa depan.

b. Manfaat Praktis

Penelitian ini diharapkan dapat dijadikan sebagai media untuk pertimbangan pengambilan keputusan oleh investor.

\section{Tinjauan Pustaka dan Hipotesis}

\section{Tinjauan Pustaka}

\section{a. Intellectual Capital}


Nick Bontis dalam (Stewart, 2010:16) (Director, Institute of Intellectual Capital Research, Associated Editor, Journal of Intellectual Capital) mengatakan "Intellectual capital merupakan mata uang baru di era millenial. Mengelolanya dengan bijaksana adalah kunci untuk kesuksesan bisnis di era knowledge".

Steward (1997) dalam (Ulum, 2017:77) mendefinisikan intellectual capital sebagai aset yang digunakan oleh perusahaan untuk dapat bersaing di pasar yang meliputi, intellectual material, pengetahuan, informasi, pengalaman dan intellectual property yang dapat digunakan untuk menciptakan kesejahteraan.

\section{b. Komisaris Independen}

Menurut peraturan Otoritas Jasa Keuangan No. 33/POJK.04/2014 bahwa dewan komisaris adalah organ penting atau perusahaan publik yang bertugas melakukan pengawasan secara umum serta memberikan nasihat kepada direksi.

Komisaris independen harus memenuhi persyaratan sebagai berikut: (1) bukan merupakan orang yang bekerja untuk merencanakan, memimpin, mengendalikan, atau mengawasi kegiatan perusahaan efek tersebut dalam waktu 6 bulan terakhir, kecuali untuk pengangkatan kembali sebagai Komisaris independen perusahaan efek pada periode berikutnya; (2) tidak mempunyai saham, baik langsung maupun tidak langsung pada perusahaan efek; (3) tidak mempunyai hubungan afiliasidengan perusahaan efek, anggota dewan komisaris, anggota direksi dan/atau pemegang saham pengendali perusahaan efek; (4) tidak mempunyai hubungan usaha baik langsung maupun tidak langsung yang berkaitan dengan kegiatan perusahaan efek.

c. Ukuran Perusahaan

Ukuran perusahaan digunakan sebagai variabel dengan asumsi bahwa perusahaan yang lebih besar akan melakukan aktivitas yang lebih banyak dan biasanya memiliki banyak unit usaha serta memiliki potensi penciptaan nilai jangka panjang (Zuhal, 2013:28).

Menurut Bapepam No. 9 tahun 1995 berdasarkan ukuran, perusahaan dapat digolongkan atas 2 kelompok sebagai berikut:

1) Perusahaan kecil

Perusahaan kecil merupakan badan hukum yang didirikan di Indonesia yang: (1) memiliki sejumlah kekayaan (total aset) tidak lebih dari 20 miliar, (2) bukan merupakan afiliasi dan dikendalikan oleh suatu perusahaan yang bukan perusahaan menengah atau kecil, (3) bukan merupakan reksadana.

2) Perusahaan besar

Perusahaan menengah atau besar merupakan kegiatan ekonomi yang mempunyai kriteria kekayaan bersih atau hasil penjualan tahunan usaha. Usaha ini meliputi usaha nasional (milik negara atau swasta) dan usaha asing yang melakukan kegiatan di Indonesia.

\section{d. Profitabilitas}

Perusahaan menjalankan usahanya guna mencari laba, para manajemen perusahaan dituntut harus mampu mencapai target yang telah direncanakan. Menurut (Kasmir, 2015:196) profitabilitas adalah rasio untuk menilai kemampuan perusahaan dalam mencari keuntungan. Rasio ini juga memberikan ukuran tingkat efektifitas manajemen suatu perusahaan. Hal ini ditunjukkan oleh laba yang dihasilkan dari penjualan dan pendapatan investasi. Intinya adalah penggunaan rasioni menunjukkan efisiensi perusahaan. 
Profitabilitas adalah faktor yang memberikan kebebasan dan fleksibilitas kepada manajemen untuk melakukan pengungkapan kepada pemegang saham secara lebih luas (Dianawati\&Fuadati, 2019). Profitabilitas yang tinggi merupakan salah satu hal yang dianggap baik oleh perusahaan, karena perusahaan cenderung mengungkapkan informasi secara detail yang bersifat mandatory maupun voluntary salah satunya informasi intellectual capital yang bertujuan untuk menaikkan nilai perusahaan (Ulum, 2017:203).

\section{Penelitian Sebelumnya}

Penelitian terkait ukuran perusahaan yang telah dilakukan oleh Astuti \& Wirama (2016) dengan hasil ukuran perusahaan berpengaruh signifikan terhadap intellectual capital, artinya, semakin besar ukuran perusahaan, maka semakin banyak perusahaan akan mengungkapkan informasi di dalam laporan tahunannya. Penelitian ini juga di dukung oleh Faradina (2015), Aprisa, dkk (2016), Sari dan Andayani (2017), serta Harahap, dkk (2018). Namun tidak sejalan dengan penelitian Asfahani (2017) yang mengungkapkan bahwa ukuran perusahaan tidak memiliki pengaruh terhadap pengungkapan intellectual capital. Serta pada penelitian lainnya dengan hasil yang sama didukung oleh penelitian dari Ashari dan Putra (2016), Rahmadhani dan Rahmawati (2016), dan Puspitarini dan Panjaitan (2018).

Penelitian terkait komisaris independen yang dilakukan oleh Poluan dan Nugroho (2015), Wahyuni dan Rasimini (2016), Rahandika dan Dewayanto (2019), Puspitarini dan Panjaitan (2018) menemukan bahwa komisaris independen berpengaruh positif terhadap Pengungkapan intellectual capital, sedangkan pada penelitian Indah dan Handayani (2017), Aini (2018), serta Yenita dan Syofyan (2018) menemukan bahwa komisaris independen tidak berpengaruh terhadap pengungkapan intellectual capital. Penelitian lain terkait profitabilitas yang dilakukan oleh Yudhanti \& Shanti (2011), Bidaki \& Hejazi (2014) dan Ashari dan Putra (2016) menemukan bahwa profitabilitas mempengaruhi pengungkapan modal intelektual. Sementara itu, Taliyang et al. (2011), Asfahani (2017), Anderrson \& Folkare (2015), Harahap, et al. (2018), Maulida (2013) dan Kateb (2014) menemukan bahwa profitabilitas tidak mempengaruhi modal intelektual.

\section{Kerangka Konsep Penelitian}

Perkembangan pengetahuan dan teknologi membuat kesadaran perusahaan tentang pengungkapan intellectual capital menjadi semakin meningkat, sehingga dianggap penting oleh perusahaan untuk memberi informasi positif kepada pihak pemangku kepentingan, menarik minat investor, serta digunakan untuk meningkatkan keunggulan daya saing yang dapat menambah nilai perusahaan.

Perusahaan yang besar memiliki jumlah investor yang tidak sedikit sehingga perusahaan dituntut dalam mengungkapkan laporan keuangan secara menyeluruh salah satunya intellectual capital. Namun perusahaan masih minim dalam penyampaian informasi secara menyeluruh kepada pengguna laporan keuangan.

Pengungkapan yang minim pada perusahaan dapat menyebabkan gap information kepada pengguna laporan keuangan sehingga peran komisaris independen sebagai pengawas manajemen untuk pembuatan laporan keuangan dianggap sebagai penghubung antara manajemen dan investor.

\section{Hipotesis}

\section{$\mathrm{H}_{1}$ : Ukuran perusahaan berpengaruh positif terhadap Pengungkapan intellectual capital.}


H2: Komisaris Independen berpengaruh positif terhadap Pengungkapan intellectual capital.

H3: Profitabilitas memperkuat pengaruh hubungan ukuran perusahaan terhadap pengungkapan intellectual capital.

$\mathrm{H}_{4}$ : Profitabilitas memperkuat pengaruh hubungan komisaris independen terhadap Pengungkapan intellectual capital.

\section{Metode Penelitian}

1. Teknik Pengumpulan Data

Berdasarkan jenisnya data yang digunakan dalam penelitian ini berupa Pooling data (cross-section pooled data). Pengumpulan data pada penelitian ini menggunakan metode content analysis. Berdasarkan karakteristik, data yang digunakan dalam penelitian ini menggunakan data sekunder. Penelitian ini menggunakan data sekunder berupa:

a. Data nama-nama perusahaan yang terdaftar pada Indeks kompas 100 selama periode penelitian 2015-2019 yang diperoleh di Bursa Efek Indonesia atau www.idx.co.id

b. Laporan tahunan perusahaan pada periode penelitian yang menjadi sampel penelitian yang didapat pada idx.co.id atau website-website perusahaan

2. Model Penelitian

\section{Gambar 2}

Model Penelitian

Variabel Independen

Variabel Dependen

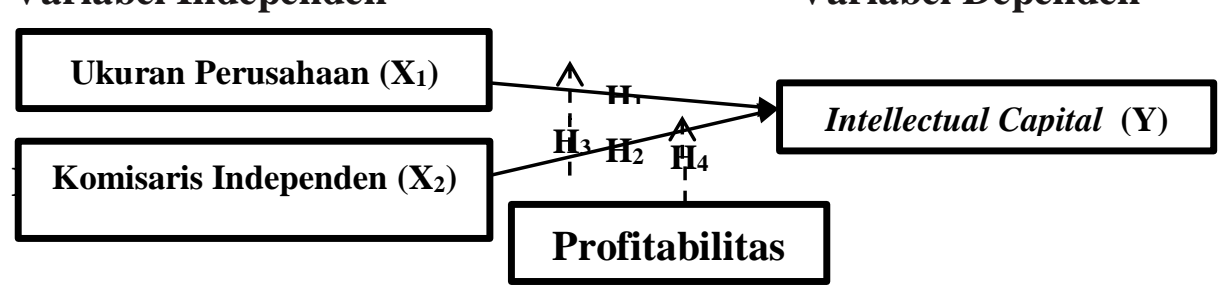

3. Definisi Operasional Variabel

Pada penelitian ini variabel dependen yang digunakan adalah pengungkapan intellectual capital (ICD). Pada penelitian ini variabel independen yang digunakan adalah ukuran perusahaan dan komisaris independen. Pada penelitian ini variabel moderasi yang digunakan adalah profitabilitas.

\section{Intellectual capital}

Pada penelitian ini, pengukuran jumlah pengungkapan intellectual capital menggunakan content analysis dengan memberikan skor 1 pada item yang diungkapkan pada laporan tahunan perusahaan dan skor 0 untuk item yang tidak diungkapkan perusahaan dalam laporan tahunan (Ulum, 2017:180).

$$
\mathrm{ICD}=\sum \mathrm{d} / \mathrm{M}
$$

$I C D=$ pengungkapan intellectual capital

$\mathrm{d}=$ nilai 1 jika item diungkapkan, nilai 0 jika item tidak diungkapkan.

$\mathrm{M}=$ jumlah keseluruhan item ( 78 item).

\section{Ukuran Perusahaan}

Ukuran perusahaan diukur dengan menggunakan total asset (Subroto, 2014:53).

Size $=$ Ln $($ Total Aset $)$ 


\section{Komisaris Independen}

Komisaris independen diukur dengan membandingkan jumlah komisaris independen dengan keseluruhan dewan komisaris (Yap, 2017:167).

KOMIN = Jumlah Komisaris Independen / Keseluruhan dewan komisaris

\section{Profitabilitas}

Profitabilitas diukur dengan membandingkan net profit atau EBITDA dengan total aset atau total ekuitas (Kasmir, 2015:201).

$$
\text { ROA = EBITDA / Total Asset }
$$

\section{Metode Analisis Data}

Untuk menganalisis hubungan antara variabel independen dengan variabel dependen, maka pengolahan data yang dilakukan dengan metode analisis regresi data panel. Analisis ini dilakukan dengan menggunakan bantuan program Eviews 9.0. model yang digunakan dalam penelitian ini sebagai berikut:

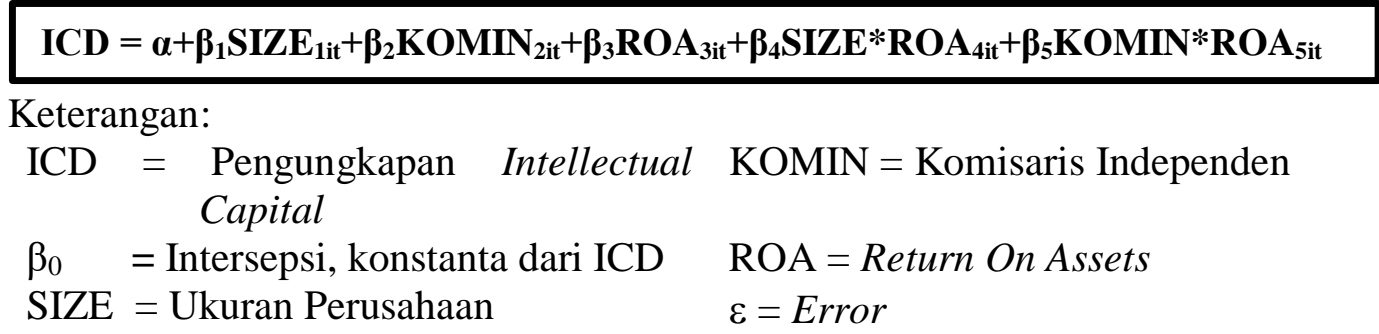

\section{Populasi, Sampel, dan Sampling Penelitian}

Populasi yang digunakan dalam penelitian ini adalah seluruh perusahaan yang tercatat di Indeks Kompas 100 Bursa Efek Indonesia tahun 2015-2019. Periode penelitian mengambil tahun terbaru laporan tahunan perusahaan diterbitkan. Teknik pengambilan sampel dilakukan dengan teknik purposive sampling dengan tujuan mendapatkan sampel yang sesuai dengan tujuan penelitian.

6. Estimasi Model Regresi Data Panel

Random Effect Model

Bentuk umum untuk random effect adalah:

ICD $_{\text {it }}=$ b $_{0}+$ b $_{1}$Size$_{1}+$ b $_{2}$Komin$_{2}+$ b ROA3 $_{3}+$ b $_{4}$ Size $^{*} \mathrm{ROA}_{4}+$ b $_{5} \mathrm{Komin}_{5} * \mathrm{ROA}_{5}+$ $\varepsilon_{i t}$ dengan $\varepsilon_{i t}=u_{i}+\mathbf{v i}_{\mathbf{i}}+\mathbf{w}_{\mathbf{i t}}$

Dimana:

$$
\begin{array}{llll}
\mathrm{b}_{0} & =\text { Nilai Konstanta. } & \mathrm{b}_{4} & =\text { Koefisien Regresi } \mathrm{b}_{4} \\
\mathrm{~b}_{1} & =\text { Koefisien Regresi } \mathrm{b}_{1} . & \mathrm{u}_{\mathrm{i}} & =\text { komponen } \text { cross section. } \\
\mathrm{b}_{2} & =\text { Koefisien Regresi } \mathrm{b}_{2} & \mathrm{v}_{\mathrm{i}} & =\text { komponen time series } . \\
\mathrm{b}_{3} & =\text { Koefisien Regresi } \mathrm{b}_{3} . & \mathrm{w}_{\mathrm{it}} & =\text { komponen } \text { error } \text { kombinasi }
\end{array}
$$

\section{Statistik Deskriptif}

Analisis statistik deskriptif digunakan untuk mengetahui tingkat pengungkapan intellectual capital yang dipengaruhi oleh ukuran perusahaan dan komisaris independen pada perusahaan yang menerbitkan laporan tahunan pada tahun 2015-2019 dan terdaftar di Indeks Kompas 100 Bursa Efek Indonesia. Pengelolaan data dari sampel menggunakan program Eviews 9.0 (Econometric Views) adalah program yang dipakai untuk analisis statistik dan ekonometrik jenis time series. Pengukuran yang digunakan dalam penelitian ini adalah mean, standar deviasi, nilai minimum, dan nilai maximum. 


\section{Uji Asumsi Klasik}

a. Uji Normalitas Data

Dalam penelitian ini menggunakan metode Jarque Bera (Gujarati dan Porter, 2013:40) dimana apabila nilai probability Jarque Bera < nilai chi-square 0,05 (5\%) dengan derajat bebas maka data dinyatakan tidak terdistribusi normal, sebaliknya apabila nilai probability Jarque Bera > nilai chi-square 0,05 (5\%) dengan derajat bebas maka data dinyatakan terdistribusi normal.

b. Uji Mutikolinearitas

Model regresi yang baik seharusnya tidak terjadi korelasi antara variabel bebas. Adanya masalah multikolinearitas dalam regresi estimasi jika besar koefisien korelasi antar variabel independen diatas 0,80 dan sebaliknya apabila nilai korelasi antar variabel berada dibawah 0,80 maka tidak adanya multikolinearitas antar variabel.

c. Uji Autokorelasi

Durbin-Watson adalah salah satu uji yang banyak dipakai untuk mengetahui ada tidaknya autokorelasi. Dalam penelitian ini menggunakan program aplikasi Eviews untuk memeriksa ada tidaknya autokorelasi.

d. Uji Heteroskedastisitas

Proses melakukan pengujian heterokedasitas pada analisis data panel dalam penelitian ini menggunakan uji glejser. Uji glejser meregresikan variabel-variabel bebas terhadap residual absolut. Residual absolut adalah selisih antara nilai observasi dengan nilai prediksi.

\section{Uji Hipotesis}

a. Uji Koefisien Determinasi $\left(\mathrm{R}^{2}\right)$

Uji koefisien determinasi $\mathrm{R}^{2}$ digunakan untuk mengukur sejauh mana model mampu menerangkan variasi variabel dependen. Nilai koefisien determinasi adalah antara nol dan satu (Wati, 2017:236). Dari nilai koefisien deterinasi $\left(\mathrm{R}^{2}\right)$ menunjukkan seberapa besar ariabel-variabel indepeden dalam menjelaskan atau mempengaruhi variabel dependen (Chandrarin, 2013:56).

b. Uji Statistik F (Uji Signifikansi Simultan)

Uji statistik F pada dasarnya menunjukkan apakah semua variabel bebas yang dimasukkan dalam model mempunyai pengaruh secara bersama-sama terhadap variabel terikat. Uji $\mathrm{F}$ dilakukan dengan menggunakan tingkat signifikan 0,05 $(\alpha=5 \%)$. Apabila nilai $F$ lebih kecil dari nilai $\alpha=5 \%$, maka variabel independen bersama-sama berpengaruh kepada variabel dependen, dan sebaliknya.

c. Uji Parameter Individual (Uji Statistik t)

Uji t menunjukkan seberapa jauh pengaruh satu variabel independen secara individual dalam menerangkan variasi variabel dependen (Ghozali, 2013:57). Pengujian dilakukan dengan menggunakan tingkat signifikansi $0,05(\alpha=5 \%)$. Kriteria untuk menerima hipotesis sebagai berikut. Jika nilai signifikansi $t \geq 0,05$, hal tersebut menujukkan bahwa secara parsial variabel independen tersebut tidak mempunyai pengaruh yang signifikan terhadap variabel dependen dan sebaliknya

\section{Hasil dan Pembahasan \\ 1. Hasil Analisis Data \\ Intellectual Capital}


Pengungkapan intellectual capital (ICD) tertinggi pada tahun 2015 dimiliki oleh perusahaan Telekomunikasi Indonesia Tbk, dengan nilai pengungkapan intellectual capital (ICD) sebesar 0,59 atau bobot 59\% dari total 78 item ICD.

Pengungkapan intellectual capital selama 2015-2019 paling banyak mengungkapkan informasi pada indikator employee, hal ini membuktikan bahwa human capital dalam perusahaan sangat penting sehingga perusahaan secara transparan mengungkapkan informasi tentang human capital yang dimilikinya. Namun pada indikator research and development perusahaan masih kurang untuk dilakukan pengungkapan, hal ini ditandai dengan rata 0,86-1,76 informasi tentang research and development yang diungkapkan oleh perusahaan-perusahaan yang dijadikan sampel selama 2015-2019.

\section{Ukuran Perusahaan}

Data ukuran perusahaan dari 22 sampel perusahaan yang masuk dalam daftar indeks kompas 100 BEI pada periode 2015-2019 ukuran perusahaan rata-rata yang paling kecil didapatkan pada tahun 2015 sebesar 30,63 dan yang paling besar pada tahun 2019 sebesar 31,10, secara keseluruhan ukuran perusahaan terendah terdapat pada perusahaan Surya Citra Media Tbk, dengan ukuran perusahaan sebesar 22,24. Ukuran perusahaan terbesar terdapat pada perusahaan Telkom Indonesia Tbk, dengan ukuran perusahaan sebesar 33,03.

\section{Komisaris Independen}

Berdasarkan data variable komisaris independen dari 22 perusahaan masuk dalam daftar Indeks Kompas 100 selama periode 2015-2019, perusahaan dengan jumlah komisaris independen yang paling sedikit dibandingkan dengan total dewan komisaris keseluruhan ada pada perusahaan Semen Indonesia Tbk (kode:SMGR) dengan variabel KOMIN sebesar 0,29 atau 29\% pada tahun 2015 dan 2017, angka tersebut menunjukan jumlah komisaris independen di perusahaan Semen Indonesia Tbk belum memenuhi batas minimal yang diatur dalam POJK No. 57 Tahun 2017 yaitu minimal $30 \%$.

\section{Profitabilitas}

Data profitabilitas dari 22 sampel perusahaan yang masuk dalam daftar Indeks Kompas 100 BEI periode 2015-2019, rasio profitabilitas terendah dimiliki oleh perusahaan Aneka Tambang Tbk pada tahun 2017 dengan tingkat profitabilitas sebesar 0,003 dan perusahaan Surya Citra Media Tbk memiliki rasio profitabilitas tertinggi sebesar 0,333 yang artinya perusahaan mampu menghasilkan laba sebesar $0.3 \%$ dari keseluruhan asset yang dimiliki.

\section{Hasil Pengujian Statistik Deskriptif}

Berikut adalah hasil dari analisis statistik deskriptif yang dapat dilihat pada tabel dibawah ini:

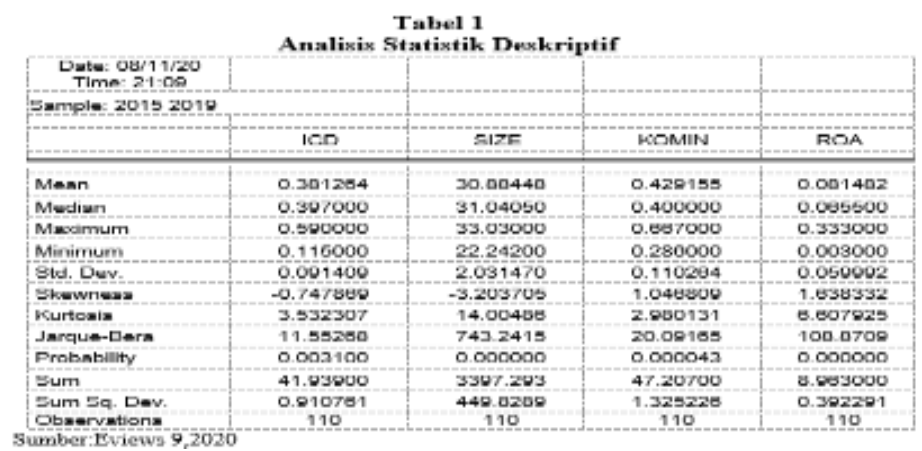

Sumber:Eviews 9,2020 
Berdasarkan tabel diatas, nilai mean yang diperoleh dari pengungkapan intellectual capital adalah sebesar 0,3812. Hal ini menunjukkan bahwa dari tahun 2015-2019 pengungkapan intellectual capital pada perusahaan yang dijadikan objek penelitian rata-rata memiliki jumlah pengungkapkan intellectual capital sebesar 0,3812 atau $38,12 \%$.

\section{Hasil Uji Asumsi Klasik}

a. Hasil Uji Normalitas Data

Berikut adalah hasil dari uji normalitas yang dapat dilihat pada tabel dibawah ini:

Tabel 2

Hasil Uji Normalitas Data

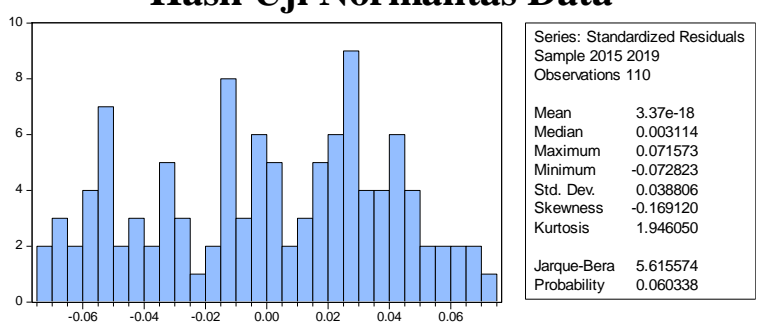

Sumber:Eviews9,2020

Berdasarkan tabel 2, hasil dari uji Jarque-Bera diperoleh probabiitas sebesar $0,060338>\alpha(0,05)$. Hasil tersebut menujukkan bahwa nilai probabilitas lebih besar dari nilai $\alpha$, sehingga hasil tersebut menunjukkan bahwa data yang digunakan terdistribusi normal.

b. Hasil Uji Multikolinearitas

c. Berikut adalah hasil dari uji multikolinearitas yang dapat dilihat pada tabel dibawah ini:

\section{Tabel 3}

\begin{tabular}{ccrr}
\multicolumn{4}{c}{ Hasil Uji Multikolinearitas } \\
& KOMIN & \multicolumn{1}{c}{ SIZE } & \multicolumn{1}{c}{ ROA } \\
\hline \hline KOMIN & 1.000000 & 0.080419 & 0.114352 \\
SIZE & 0.080419 & 1.000000 & -0.577424 \\
ROA & 0.114352 & -0.577424 & 1.000000
\end{tabular}

Sumber: Eviews9, 2020

Dari tabel 3 nilai-nilai yang didapatkan menunjukan bahwa nilai antar korelasi < 0,80 , sehingga tidak terjadi multikolinearitas pada penelitian ini.

\section{d. Hasil Uji Autokorelasi}

Uji Autokorelasi menggunakan metode Durbin-Watson dengan ketentuan sebagai berikut.

\section{Tabel 5}

\section{Hasil Uji Autokorelasi}

Weighted Statistics

\begin{tabular}{llll}
\hline \hline R-squared & 0.911851 & Mean dependent var & 0.587806 \\
Adjusted R-squared & 0.885616 & S.D. dependent var & 0.411347 \\
S.E. of regression & 0.041866 & Sum squared resid & 0.147235 \\
F-statistic & 34.75734 & Durbin-Watson stat & 1.830749 \\
Prob(F-statistic) & 0.000000 & & \\
Sumber: Eviews9,2020 & & &
\end{tabular}


Berdasarkan tabel 5 hasil output nilai Durbin Watson dalam penelitian ini adalah sebesar 1,830749, nilai $\mathrm{D}_{\mathrm{L}}=1,6523 ; \mathrm{D}_{\mathrm{U}}=1,7262 ; 4-\mathrm{D}_{\mathrm{L}}=2,377$; dan 4- $\mathrm{D}_{\mathrm{U}}=2,2738$. Sehingga hasil yang didapat berdasarkan kriteria Durbin Watson adalah sebagai berikut $1,7262 \leq 1,830749 \leq 2,2738$ yang menunjukkan bahwa tidak terjadi autokorelasi antar variabel.

e. Hasil Uji Heterokedasitas

Berikut adalah hasil dari uji Heterokedasitas yang bisa dilihat pada tabel dibawah ini:

Tabel 6

Hasil Uji Heterokedasitas

\begin{tabular}{|c|c|c|c|c|}
\hline \multicolumn{5}{|l|}{ Sample: 20152018} \\
\hline \multicolumn{5}{|c|}{ Periods included: 5} \\
\hline \multicolumn{5}{|c|}{ Cross-sections included: 22} \\
\hline \multicolumn{5}{|c|}{ Total panel (balanced) observations: 110} \\
\hline \multicolumn{5}{|c|}{ Linesr estimation after one-step weighting matrix } \\
\hline Variable & Coefficient & Std. Error & t-Statistic & Prob. \\
\hline $\mathrm{c}^{-}$ & -0.042419 & 0.259701 & -0.16333 & 0.8708 \\
\hline SIZZE & 0.002750 & 0.008428 & 0.32635 & 0.7450 \\
\hline KOMIN & 0.043285 & 0.028486 & 1.519544 & 0.1323 \\
\hline
\end{tabular}

Sumber:Eviews9,2020

Berdasarkan tabel 6 pada model regresi penelitian dari semua variabel independen penelitian ini nilai probabilitasnya sebesar $>\alpha(0,05)$. Sehingga dapat disimpulkan tidak terjadi heterokedasitas pada penelitian ini.

f. Hasil Analisis Regresi Data Panel

Hasil regresi dapat dilihat pada tabel 4.17 yang disajikan sebagai berikut:

Tabel 7

Model Fixed Effect dengan metode GLS

\begin{tabular}{|c|c|c|c|c|}
\hline Variable & Coefficient & Std Errof & t-Statistic & Prob. \\
\hline $\mathrm{c}$ & -0.510180 & 0.479484 & -1.084020 & 0.2904 \\
\hline SIZE & 0.027240 & 0.018020 & 1.700722 & 0.0027 \\
\hline SIZE ROA & 0.033750 & 0.007921 & 4.261718 & 0.0001 \\
\hline KOMMIN & 0.105978 & 0.051143 & 2.072185 & 0.0413 \\
\hline KOMIN_ROA & -2.188983 & 0.454913 & -4.807471 & 0.0000 \\
\hline & \multicolumn{2}{|c|}{ Effects Specification } & & \\
\hline \multicolumn{5}{|c|}{ Cross-section fixed (dummy variables) } \\
\hline & \multicolumn{2}{|c|}{ Weighted Statistics } & & \\
\hline R-squared & 0.911851 & \multicolumn{2}{|c|}{ Mesn dependent var } & 0.587806 \\
\hline Adjusted R-squared & 0.885810 & \multicolumn{2}{|c|}{ S.D. dependent var } & 0.411347 \\
\hline S.E. of regression & 0.041860 & & 0.147235 \\
\hline F-statistic & 34.75734 & \multicolumn{2}{|c|}{$\begin{array}{l}\text { Sum squared resid } \\
\text { Durbin-Watson stat }\end{array}$} & 1.830748 \\
\hline Prob(F-statistic) & 0.000000 & & & \\
\hline
\end{tabular}

Sumber:Eviews9, 2020

Berdasarkan pada tabel 4.17 maka model regresi yang dirumuskan adalah

\section{ICD $=-0,510180+0,0272746$ SIZE $_{i t}+0,105978 K O M I N_{i t}+$ 0,033759SIZE*ROA ${ }_{i t}-2,186983 K O M I N * R O A_{i t}$ e}

Analisis hasil regresi data panel adalah sebagai berikut :

1. Hasil regresi menunjukan nilai konstanta yang diperoleh dari penelitian ini sebesar 0,510180, yang menunjukkan bahwa apabila nilai koefisien SIZE dan KOMIN, mendapatkan 0 maka nilai pengungkapan intellectual capital sebesar 0,510180 .

2. Nilai koefisien SIZE yang diperoleh dari penelitian ini sebesar 0,0272746 , hasil ini menunjukkan bahwa setiap nilai variabel Ukuran Perusahaan bertambah 1 
maka nilai konstanta pengungkapan intellectual capital akan bertambah sebesar 0,0272746 .

3. Nilai koefisien KOMIN yang diperoleh dari penelitian ini sebesar 0,150978, yang menunjukan keadaan dimana setiap nilai variabel komisaris independen bertambah 1 maka nilai konstanta pengungkapan intellectual capital akan naik sebesar 0,105978

4. Nilai Koefisien SIZE*ROA yang diperoleh dari penelitian ini sebesar sebesar 0,033759, yang menunjukan bahwa setiap nilai variabel moderasi size dengan roa bertambah 1 maka nilai konstanta pengungkapan intellectual capital akan naik sebesar 0,033759

5. Nilai Koefisien KOMIN*ROA yang diperoleh dari penelitian ini adalah sebesar -2,186983, yang menunjukkan keadaan dimana saat komisaris independen dimoderasi oleh variabel profitabilitas dikurang 1 maka nilai konstanta pengungkapan intellectual capital akan turun sebesar -2,186983.

\section{Uji Hipotesis}

a. Koefisies Determinas $\left(\mathbf{R}^{2}\right)$

Hasil koefisien determinasi dapat dilihat pada tabel dibawah ini:

\section{Tabel 8}

\section{Hasil Uji Koefisien Determinasi}

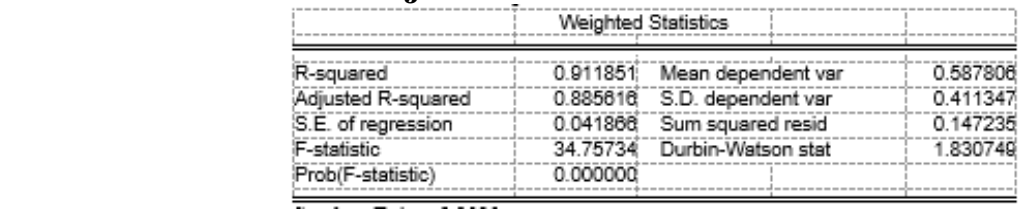

Sumber: Eviews9,2020

Berdasarkan tabel 8 diatas hasil nilai dari Adjusted $R$-Square sebesar 0,885616 . Hal ini menunjukan bahwa $88,56 \%$ pengungkapan intellectual capital dapat dijelaskan oleh variabel yang digunakan pada penelitian. Sedangkan 11,44\% diterangkan oleh faktor lain diluar variabel yang digunakan seperti leverage, kepemilikan managerial, kepemilikan pemerintah, kepemilikan institusional, komite audit, dll.

b. Hasil Uji F

Berdasarkan hasil perhitungan menunjukkan bahwa nilai probabilitas $<0,05$ yaitu sebesar 0,0000000. Sehingga dapat disimpulkan bahwa variabel size, dan komisaris independen bersama-sama mempengaruhi pengungkapan intellectual capital atau dengan kata lain bahwa model regresi layak digunakan untuk penelitian ini.

\section{Pembahasan}

a. Pengaruh Ukuran Perusahaan terhadap Pengungkapan Intellectual Capital

Hasil analisis data menunjukkan bahwa ukuran perusahaan memiliki nilai koefisien 0,027246 dengan tingkat signifikan 0,0927 <0,10. Menurut statistik variabel ukuran perusahaan memiliki pengaruh signifikan positif terhadap pengungkapan intellectual capital.

b. Pengaruh Komisaris Independen terhadap Pengungkapan Intellectual Capital 
Hasil analisis data menunjukkan bahwa variabel komisaris independen (KOMIN) memiliki nilai koefisien sebesar 0,105978 dengan tingkat signifikan sebesar 0,00413 < 0,10. Dapat dikatakan Komisaris Independen berpengaruh positif terhadap Pengungkapan Intellectual capital. Hal tersebut menujukkan bahwa $\mathrm{H}_{0}$ ditolak dan $\mathrm{H}_{2}$ diterima.

c. Profitabilitas memoderasi pengaruh hubungan Ukuran Perusahaan terhadap Pengungkapan Intellectual Capital

Nilai probability interaksi Ukuran Perusahaan dengan Profitabilitas adalah sebesar $0,00001<0,10$ dengan nilai t-statistik, hal tersebut menunjukkan bahwa $\mathrm{H}_{0}$ ditolak dan $\mathrm{H}_{3}$ diterima. Hal ini menunjukkan bahwa profitabilitas berpengaruh signifikan positif sebagai pemoderasi ukuran perusahaan terhadap pengungkapan intellectual capital.

d. Profitabilitas memoderasi pengaruh hubungan Komisaris Independen terhadap Pengungkapan Intellectual Capital.

Nilai probability interaksi Komisaris Independen dengan Profitabilitas adalah sebesar $0,00000<0,10$ dengan nilai coefficient -2.186983 , hal tersebut menunjukkan bahwa $\mathrm{H}_{3}$ ditolak. Hal tersebut menunjukkan bahwa profitabilitas memperlemah pengaruh komisaris independen terhadap pengungkapan intellectual capital.

\section{Simpulan dan Keterbatasan}

\section{Simpulan}

Berdasarkan hasil analisis data dan pengujian data dalam penelitian ini maka dapat ditarik kesimpulan sebagai berikut:

a. Ukuran perusahaan berpengaruh signifikan positif terhadap pengungkapan intellectual capital. hal ini menunjukkan bahwa semakin besar ukuran perusahaan maka akan semakin besar tingkat pengungkapannya. Perusahaan yang besar memiliki jumlah investor yang banyak sehingga perusahaan akan melakukan transparansi pengungkapan informasi perusahaan sebagai bentuk tanggungjawab perusahaan kepada pemegang modal.

b. Komisaris independen berpengaruh positif terhadap pengungkapan intellectual capital. hal ini menunjukkan bahwa dengan banyaknya jumlah komisaris independen pada suatu perusahaan akan membuat pengawasan menjadi lebih optimal sehingga manajemen tidak dapat melakukan kegiatan manipulatif pada pelaporan informasi perusahaan.

c. Profitabilitas memperkuat pengaruh ukuran perusahaan terhadap pengungkapan intellectual capital. profitabilitas mampu memperkuat pengaruh ukuran perusahaan terhadap pengungkapan intellectual capital hal ini menunjukkan ukuran perusahaan yang besar akan diikuti dengan tingkat profitabilitas yang tinggi sehingga perusahaan akan memilih untuk mengungkapkan informasi intellectual capital sebagai sinyal bagi investor untuk menanamkan sahamnya pada perusahaan tersebut.

d. Profitabilitas tidak mampu memperkuat pengaruh komisaris independen terhadap pengungkapan intellectual capital. Hal ini dikarenakan komisaris independen akan berusaha untuk memperluas transparansi informasi perusahaan kepada pengguna laporan keuangan dengan tidak mempertimbangkan tinggi rendahnya tingkat profitabilitas suatu perusahaan.

\section{Keterbatasan}


a. Penelitian ini hanya menggunakan framework 78 yang dikembangkan oleh Bukh et al. (2005).

b. Penelitian ini hanya sebatas meneliti variabel ukuran perusahaan dan komisaris independen.

\section{Saran}

Berdasarkan hasil kesimpulan diatas, maka saran hasil penelitian sebagai berikut:

a. Disarankan dalam penelitian selanjutnya agar menggunakan variabel selain ukuran perusahaan dan komisaris independen seperti Komite Audit dan Ownership Retention.

b. Disarankan untuk penelitian selanjutnya untuk meneliti moderasi selain profitabilitas seperti Kepemilikan Asing.

\section{DAFTAR PUSTAKA}

Aini, S., n.d. Pengaruh Karakteristik Dewan Komisaris dan Direksi terhadap Pengungkapan Intellectual Capitl. Jurnal Akuntansi Fakultas Ekonomi Universitas Negeri Padang. Vol 6 (1), pp: 1-20.

Aprisa, R., Rusli, A., \& Silfi, A. 2016. Pengaruh Ukuran Perusahaan, Profitabilitas, Tipe Auditor ,dan Tipe Industri terhadap Pengungkapan Modal Intelektual.JOM Fekom, Vol. 3(1):1393-1406

Asfahani, E. S. 2017. Pengaruh Ukuran Perusahaan, Profitabilitas, Leverage, Umur Perusahaan dan Kepemilikan Pemerintah terhadap Pengungkapan Intellectual Capital. Jurnal Ekonomi Akuntansi, Vol. 3 (3), pp: 40-61.

Ashari, P. M. S., \& Putra, I. N. W. A. 2016. Pengaruh Umur Perusahaan, Ukuran Perusahaan, Profitabilitas, Leverage dan Komisaris Independen terhadap Pengungkapan Modal Intelektual. E-Jurnal Akuntansi Universitas Udayana, Vol. 16 (3), pp:1699-1726.

Astuti, N., \& Wirawa, D. 2016. Pengaruh Ukuran Perusahaan, Tipe Industri, dan Intensitas Research and Development pada Pengungkapan Modal Intelektual. EJurnal Akuntansi Universitas Udayana, Vol. 15 (1), pp:522-548.

BAPEPAM Nomor 9 Tahun 1995 tentang Usaha Kecil.

Bidaki, S. \& Hejazi, R. 2015. Effect of Profitability on the Intellectual Capital disclosure in Listed Companies in Tehran Stick Exchange. International Journal of Education and Applied Sciences, Vol. 1 (5), pp: 248-255.

Bontis, N. 2010. Managing organizational Knowldge by Diagnosing Intellectual Capital. In N. Bontis, \& C. W. Choo, The Strategic Management of Intellectual Capital and organizational Knowldge (p. 621). New York: Oxford University Press.

Chandrarin, G., 2017. Metode Riset Akuntansi. Jakarta: Salemba Empat.

Firer, S., \& William, S. 2005. Firm Ownership Structure and Intellectual Capital Disclosure. Sajar, Vol. 1(3), pp:1-18.

Ghozali, I., 2013. Analisis Multivariat dan Ekonometrika Teori, Konsep dan Aplikasi dengan Eviews. Yogykarta: Universitas Diponegoro.

Godfrey, J., Hodgson, A., Tarca, A., Hamilton, J., \& Holmes, S. 2010. Accounting Teory. Australian: John Wiley \& Sons.

Gujarati, D. N. \& Porter, D. C., 2013. Dasar-Dasar Ekonometrika. 5nd ed. Jakarta: Salemba Empat. 
Harahap, R. A. P., Kristanti, F. T. \& Dillak, V. J., 2018. Analisa Pengaruh Leverage, Profitabilitas dan Ukuran perusahaan terhadap Pengungkapan Modal Intelektual. e-Proceeding of Management, Vol.5(1), pp:504.

Indah, N dan Handayani, S. 2017. Pengaruh Corporate Governance terhadap Intellectual Capital Disclosure. Diponegoro Journal of Accounting. Vol. 6(3), pp: 1-8.

Kar, J. K., Khavandkar, E., \& Motaghi, A. 2013. Intellectual capital: Management, Development, and Measurement Model. Iran: Indutrial Research and Training Center of Iran Press.

Kariyoto. 2018. Manajemen Keuangan Konsep dan Implementasi. Malang: UB Press.

Kasmir. 2015. Pengantar Manajemen Keuangan. Jakarta: Kencana.

Keputusan Menteri BUMN KEP-117/M-MBU/2002 tanggal 31 Juli 2001. Penerapan Praktik Good Corporate Governance pada Badan Usaha Milik Negara (BUMN).

Kieso, D. E., Weygandt, J. J., Warfield, T. D. 2012. Intermediate Accounting ed:14 ${ }^{\text {th }}$. Jakarta: Salemba Empat.

Komite Nasional Kebijaka Governance. 2006. Pedoman Etika Bisnis. PT. Elex Media Komputindo.

Li, J., Pike, R., \& Haniffa, R. 2008. Intellectual capital Disclosure and Corporate Governance Stucture in UK Firm. Accounting and Bussiness Research, Vol. 38(22), pp: 137-159

Maulida, A. 2013. Analisis Pengaruh Ukurang Perusahaan, Umur Perusahaan, Kepemilikan Publik, Profitabilitas, dan Leverage terhadap Tingkat Pengungkapan Intellectual Capital. Universitas Islam Negeri Suna Kalijaga.

Peraturan Otoritas Jasa keuangan Nomor 55/ POJK.03/2016. Tentang Penerapan Tata Kelola Bagi Bank Umum

PSAK No. 1 tentang Penyajian laporan Keuangan. Ikatan Akuntansi Indonesia.

PSAK No. 19 (revisi 2015) tentang aset tidak berwujud. Ikatan Akuntansi Indonesia.

POJK Nomor 33/ POJK.04/2014 tentang Direksi dan Dewan Komisaris Emiten atau Perusahaan Publik.

POJK Nomor 57/POJK.04/2017. Peraturan Otoritas Jasa Keuangan tentang Penerapan Tata kelola Perusahaan Efek yang Melakukan Kegiatan Usaha sebagai Penjamin Emisi Efek dan Perantara Pedagang Efek.

Poluan, G. \& Nugroho, P. I., 2015. Pengaruh Mekanisme Corporate Governance dan Kondisi Financial Distress Terhadap Luas Pengungkapan Sukarela Dalam Laporan Tahunan Perusahaan. Dinamika Akuntansi, Keuangan dan Perbankan, Vol. 4(1), pp. 39-56.

Prasetyantoko, A. 2010. CORPORATE GOVERNANCE:Pendekatan Institusional. Jakarta: Gramedia Pustaka Utama

Puspitarini, P. A. \& Panjaitan, Y., 2018. Pengaruh Tata, Kinerja, dan Karakteristik Perusahaan Terhadap Pengungkapan Modal Intelektual Perusahaan Property dan Real Estate. Ultima Accounting, Vol. 10(2), pp: 150-168.

Rahandika, F., \& Dewayanto, T. 2019. Peran tata Kelola Perusahaan pada Pengungkapan Modal Intelektual. Diponegoro Journal of Accounting, Vol. 8(3), pp: 1.

Rahmadhani, S. \& Rahmawati, I. N. 2016. Pengaruh Penerapan IFRS Berdasarkan Karakteristik Perusahaan Terhadap Pengungkapan Intellectual Capital. Jurnal Ilmu Manajemen dan Akuntansi Terapan, Vol. 6(2), pp: 133-158

Rahmawati, S. \& Faisal. 2017. Konflik Keagenan dan Tata Kelola Perusahaan di Indonesia. Banda Aceh: Syiah Kuala University Press. 
Taliyang, S. M. \& Jusop, M., 2011. Intellectual capital Disclosure and Corporate Governance Stucture. International Journal of Business and management, Vol. 6(12), pp: 109-117.

Tandelilin, E. 2010. Portofolio dan Investasi. Yogyakarta: Kanisius.

Prasetyantoko,. 2016. Akuntansi Perbankan Syariah dari Teori ke Praktik. Yogyakarta: Deepublish.

Sari, M. H., \& Andayani, 2017. Pengaruh Kinerja Intellectual Capital , Leverage dan Size terhadap Pengungkapan Intellectual Capital. Jurnal Ilmu dan Riset Akuntansi, Vol. 6(1), pp: 23-41

Sartono, A. 2010. Manajemen Keuangan Teori dan Aplikasi. Ed:4th . Yogyakarta: BPFE.

Stewart, T. A. 2010. Intellectual Capital The New Wealth of OrgaP. Pengungkapan Wajib Perusahaan Publik Kajian Teori dan Empiris. Malang: UB Press.

Wijayanto, D. 2012. Pengantar Manajemen. Jakarta: PT. Gramedia Pustaka Utama.

Yadiati, W. \& Mubarok, A. 2017. Kualitas Laporan Keuangan: Kajian Teoritis dan Empiris. Jakarta: Kencana.

Yap, P. 2017. Panduan Praktis Manajemen Risiko Perusahaan. Jakarta: Growing Publishing.

Yenita, R. \& Syofyan, E. 2018. Pengaruh Karakteristik, Kinerja Perusahaan, dan Diversitas Dewan Komisaris Terhadap Pengungkapan Modal Inteletual. Jurnal WRA, Vol.6(1), pp: 24-35.

Yudhanti, C. B. H. \& Shanti, J. C. 2011. Intellectual Capital dan Ukuran Fundamental Kinerja Keuangan Perusahaan. Jurnal Akuntansi dan Keuangan, Vol.13(2), pp: 5766.

Zuhal. 2013. Kekuatan Daya Saing Indonesia: Mempersiapkan Masyarakat Berbasis Pengetahuan.Jakarta: PT. Kompas Nusantara

www.idx.co.id

www.ojk.go.id

www.iaiglobal.or.id 